South African Journal of Geomatics, Vol. 4, No. 2, June 2015

\title{
Geophysical monitoring of coastal erosion and cliff retreat of Monwabisi Beach, False Bay, South Africa
}

\author{
Michael MacHutchon ${ }^{1}$ \\ ${ }^{1}$ Council for Geoscience, 3 Oos Street, Bellville, 7535, Cape Town, South Africa
}

DOI: http://dx.doi.org/10.4314/sajg.v4i2.2

\begin{abstract}
Monitoring of the coastal zone is necessary to assess its vulnerability and help formulate coastal management plans. A predetermined stretch of beach along the northern rim of False Bay known locally as Monwabisi Beach was chosen to compare different monitoring techniques and from the data acquired, see if accurate comment could be made regarding sediment dynamics and its implications regarding any coastal encroachment on anthropogenic infrastructure.

Digital elevation models of the study area were created from data acquired with a mobile laser scanner in April 2013, April 2014 and August 2014, chosen to cover a yearly and a seasonal cycle. Conventional beach profile data were acquired using a differential global positioning system (DGPS) in April 2014 and LiDAR data were acquired in November 2014.

From the laser scanning datasets it has been calculated that a nett erosional trend exists for the study area with sediment moving towards the north. In the western portion of the study area, where a coastal road has been undercut and complete failure has occurred, the progress of cliff retreat has been accurately measured to reveal an average rate of retreat of $2.2 \mathrm{~m} / \mathrm{yr}$. Although accurate figures were determined for sediment erosion and accretion, the rate of change of each could not be determined with any degree of confidence as the survey intervals were not regular enough to consider nett amounts; rather the gross amounts have been presented.
\end{abstract}

\section{Introduction}

Approximately $40 \%$ of South Africa's population live within $100 \mathrm{~km}$ of the coast (Unterner et al., 2011) and coastal resources are relied on for commercial opportunities as well as for food, recreation and transport, thereby facilitating job creation and general economic upliftment. The coastal zone is subject to significant anthropogenic modifications and both coastal ecosystems and 
human populations are especially susceptible to the negative impacts of any changes, including natural geohazards.

Quantification of erosion and accretion rates of sediment dynamics in the coastal zone is invaluable for the formulation of coastal management plans. Regular monitoring is necessary to formulate these management plans which rely upon the acquisition of high precision digital elevation models (DEM) to characterise the geomorphology of the coastline. Furthermore, multiple and regular acquisitions of DEM data can be used to monitor erosion or sedimentation rates.

Several techniques for the extraction of elevation data have been developed. These techniques include 1) traditional field-based DGPS surveys, 2) photogrammetric techniques applied to aerial photographs or satellite imagery, 3) the acquisition of LiDAR data through terrestrial or airborne campaigns and 4) from synthetic aperture radar data through interferometric image processing techniques. This research aims to assess some of the more affordable techniques to extract high resolution and high precision digital elevation data. A local test site was selected called Monwabisi Beach which is located along the northern margin of False Bay in the Western Cape Province of South Africa (Figure 1). Furthermore, multiple data acquisitions were used to quantify the sediment dynamics in the area of interest with the focus on the development of tools for the long term monitoring and quantification of sediment dynamics. 


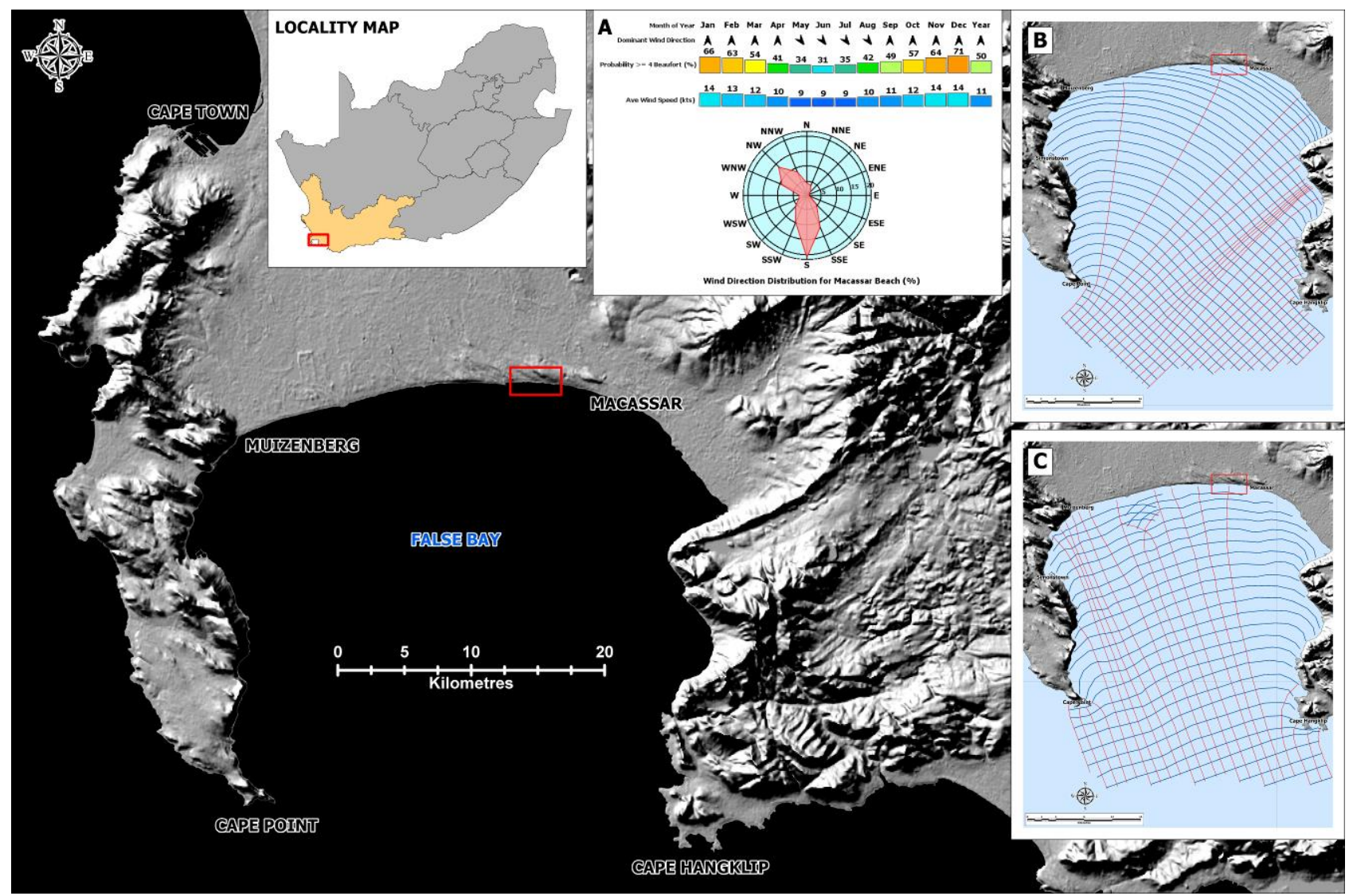

Figure 1. Location of Monwabisi Beach (red rectangle) relative to False Bay. Historical wind data for Macassar Beach from 2000-2014 modified from Windfinder (2014) (A). Wave refraction models for False Bay (B \& C) modified from Terhorst (1988).

\section{Physical oceanographic setting}

\subsection{Wind patterns}

Climatic conditions along the western margin of South Africa (from Cape Point to Namibia) are primarily influenced by meteorological effects originating offshore in the Atlantic and Southern Oceans. Anticyclonic conditions originate at approximately $30^{\circ} \mathrm{S}$ as a result of a subtropical highpressure zone in the Atlantic Ocean, and easterly moving cyclonic cells develop between $35^{\circ} \mathrm{S}$ and $40^{\circ} \mathrm{S}$. The relative locations of these features vary seasonally by either a poleward or an equatorward shift of approximately $3^{\circ}$ (MacHutchon, 2008; Hutchings et al., 2009; MacHutchon, 2013). False Bay is situated at approximately $34^{\circ} \mathrm{S}$ which means it is dominated by anticyclonic winds in summer and cyclonic conditions in winter (Van Foreest and Brundrit, 1985; Van Foreest and Jury, 1985; Terhorst, 1988) (Figure 1 A). 


\subsection{Wave regime}

Because False Bay is almost rectangular in shape and opens only to the south, it is primarily only affected by deep ocean swells generated from the southwest and south southeast (Rossouw, 1984; Terhorst, 1988; Theron and Schoonees, 2007). Seafloor and coastal morphology all have an effect on the wave refraction patterns experienced by the bay and ultimately the study area along its northern margin (Figure $1 \mathrm{~B} \& \mathrm{C}$ ).

From 1980 to 1981 wave data were recorded for two localities near the study area (Swart and Schoonees, 1994; Theron and Schoonees, 2007). Two wave rider buoys were placed in approximately $20 \mathrm{~m}$ of water and collected data spanning one year. From these data the mean significant wave height recorded was $1.2 \mathrm{~m}$ with a mean peak wave period of $11.1 \mathrm{~s}$ (Theron and Schoonees, 2007). During two months of 1994 wave and current measurements were recorded for Monwabisi Beach (Schoonees et al., 1999). In 10m of water the significant wave height recorded was $2.9 \mathrm{~m}$ with the maximum significant wave height determined to be $4.4 \mathrm{~m}$ and an average peak period of $13 \mathrm{~s}$ (Theron and Schoonees, 2007). Wave incidence angles were recorded at approximately $5^{\circ}$. The flat nearshore morphology dictates a typically wide surf zone of approximately $270 \mathrm{~m}$ becoming a maximum of 530m during extreme storm events. Wind waves commonly form during the summer month southerly gales (Theron and Schoonees, 2007).

\subsection{Tidal environment}

The tides in False Bay are semi-diurnal with an average mean spring tidal range of $-0.6 \mathrm{~m}$ to $0.95 \mathrm{~m}$ relative to mean sea level (MSL). This gives an absolute tidal range of $1.55 \mathrm{~m}$ (SAN, 2014) which classifies False Bay into a microtidal $(<2 \mathrm{~m})$ regime (Terhorst, 1988). The highest predicted astronomical tide is $1.25 \mathrm{~m}$ above MSL which can be exceeded as a result of wave setup which is the effect waves have on top of the tidal variation (Theron and Schoonees, 2007). Another effect to be considered is wave run-up which is the degree/distance the water runs up the swash zone of the beach. These two factors can result in an increase in the landward extent of the highest water level. The wave run-up exceeded for $2 \%$ of the time during a typical storm along the northern rim of False Bay has been calculated at approximately $1.7 \mathrm{~m}$ (CSIR, 1983). The combination of all of these factors results in the most landward extent of the ocean being approximately $3 \mathrm{~m}$ above MSL for the study area (Theron and Schoonees, 2007).

\subsection{Nearshore and surface currents}

The two driving mechanisms of the nearshore and surface currents are longshore drift and prevailing wind vectors. Swells from the southwest induce a longshore drift current directed 
towards the east (Theron and Schoonees, 2007). Northwesterly winds will induce a component of clockwise circulation within False Bay (Atkins, 1970), with the converse true for southeasterly winds and swells originating from the southeast. It has been shown by Theron and Schoonees (2007) that when the eastward flowing longshore drift vector encounters prominatory structures such as groynes or jetties, an eddy current forms on the inshore region such as what is observed at the Monwabisi Beach tidal pool.

\section{Methods}

For the purpose of this investigation three different techniques were employed for acquiring information about the shape of the beach profile or DEM of the study area. Two of the techniques utilise LiDAR technology (which is an acronym for Light, Detection and Ranging) which utilises the time taken for a laser beam to be sent from a source to a target, reflecting back to the source. The third revolves around measuring the height of a GPS receiver along traverses across the beach and reducing this height down to ground level. In this report laser scanning refers to a LiDAR type system mounted to a car and driven around the study area and LiDAR to a similar type system mounted to a fixed wing aircraft, flown above the study area. The beach profiling refers to the system where a GPS antenna height is used to define the shape of shore perpendicular transects. In terms of resolution the laser scanning yielded the highest resolution DEM as the laser source was closer to the scanning targets whereas the airborne LiDAR was flown at a height of $1000 \mathrm{~m}$. The beach profiling collected a data point every second along the profiles collected yet the profile lines were approximately $560 \mathrm{~m}$ apart therefore the resultant DEM would be in the order of $280 \mathrm{~m}$.

For the acquisition of the laser scanning data a Riegl VZ-400 scanner was used. It was mounted on the roof of a $4 \times 4$ SUV (survey platform) and configured as a vertical (line) scanner to scan normal to the direction of movement. The scanning angle ranged from $40^{\circ}$ below to $60^{\circ}$ above the horizontal at a scan rate of 120lines/sec with an angular measurement resolution of better than $0.0005^{\circ}$. The effective range was approximately $100 \mathrm{~m}$ and was governed by topographic elevation of scanning targets. Where too high an "optical shadow" is cast by the target on the side farthest from the scanner. The scanner was interfaced with an Applanix POS MV 320 motion reference unit to correct for the dynamic motion of the survey platform. The POS MV outputs all motion variables at rates of up to $200 \mathrm{~Hz}$ even in the presence of GPS dropouts or degraded DGPS corrections. Position and accurate height (relative to a levelled benchmark within the survey area) information was provided to the geophysical survey suite by a Leica real-time kinematic (RTK) system. The Leica uses a GNSS GS15 receiver and built in radio transmitters. The superior GNSS technology 
allows for very low noise GNSS carrier phase measurements, with less than $0.5 \mathrm{~mm}$ precision. The data from these devices were acquired and processed using Qinsy and Fledermaus software.

Beach profiling was conducted using a Carlson GIS handheld RTK rover. The setup consists of a GPS receiver with colour display for navigation and a GNSS antenna mounted on a pole and secured to a backpack. The GPS receiver obtains base station corrections via the TRIGNET survey network over a GSM network. A dipole antenna was integrated for improved GSM reception.

The LiDAR data were acquired by Southern Mapping Geospatial using an Optech Orion M200 ALTM LiDAR scanner and PhaseOne iXA180 camera. These devices were installed on a Partenavia P68 aircraft and flown at a height of 1,000m.

\section{Results}

\subsection{Elevation datasets}

Laser scanning elevation datasets were collected in April 2013, April 2014 and August 2014. The data therefore spans a yearly cycle as well as a typical summer-winter seasonal cycle. The topographic data collected ranged between $25.89 \mathrm{~m}$ above and $2.09 \mathrm{~m}$ below MSL. These data covered a swathe of between $150 \mathrm{~m}$ to $280 \mathrm{~m}$, (depending on the elevation of the topographic highs) and covered a distance of approximately 3,420m. The different morphological zones of a typical beach profile are clearly evident although their respective widths vary as one moves through the survey block. The beach berm is clearly defined along the entire length of beach surveyed. Towards the west of the survey block the berm is defined by competent rock outcrop and as one transects to the east it is defined by the accumulation of sand on the maximum range of the swash zone at high tide. The average slope of the berm is approximately $8^{\circ}$, flattening to slopes of approximately $1^{\circ}$ both shoreward and landward of this relative high. Towards the eastern part of the study area the berm morphology changes in character from a straight sinuous ridge to one characterised by beach cusps. The cusps occur $560 \mathrm{~m}$ from the eastern extent of the acquired data and display an approximate spacing of $34 \mathrm{~m}$. The most morphologically varied zone of the beach profile is the backbeach/foredune area. This zone is typically characterised by small resistant highs and exhibits an undulose microtopography which then grades into the much steeper coastal dunes seen just inland of the survey area. The dune crests have aligned themselves parallel to the dominant incident wind vector with an approximate strike of $303 / 123^{\circ}$.

The LiDAR data were acquired during November 2014. The dataset collected covered a much larger area than that of the laser scanner as the Monwabisi study area alone was too small to warrant the high mobilisation costs. It was therefore decided to collect a dataset covering a swathe of 
approximately 500m and a distance of 27,900m from Macassar Beach in the east to Muizenberg in the west. The data collected ranged between $67.20 \mathrm{~m}$ above and $1.40 \mathrm{~m}$ below the South African Geoid Model 2010 (SAG2010). The same morphological trends observed in the laser scanning datasets were observed within the LiDAR dataset although at coarser resolution. The LiDAR data does include a near vertical sea cliff area to the west of the study area which is completely inaccessible from the beach.

\subsection{Beach profile comparisons}

Six shore perpendicular transects have been constructed across the study area (inset map Figure 2). These transects have been spaced so that they are roughly equidistant from one another. The spacing was determined by the profiles collected using the Carlson DGPS during April 2014. Using these profiles allowed for accurate comparison to be made between the different datasets and the different techniques used to acquire the elevation data. The transects are numbered from west to east with the beach composition grading from a more rocky undulose substrate to the sandy "conventional" beach profile. The relative position of the beach berm is evident on all of the transects, characterised by the most seaward inflection point on all of the recorded profiles.

For each profile there is a cluster of lines denoting the laser scanning datasets and two offset (red and yellow) lines denoting the Carlson DGPS and LiDAR elevation data respectively (Figure 2). These profiles appear to be offset from the other data by approximately $1.5 \mathrm{~m}$ to $2 \mathrm{~m}$. The most plausible explanation for this is that the SAG2010 geoidal model is referenced to a different vertical datum than MSL. As a result of this, only the common datasets of the laser scanner were used for volume computations and to comment on morphological changes. 


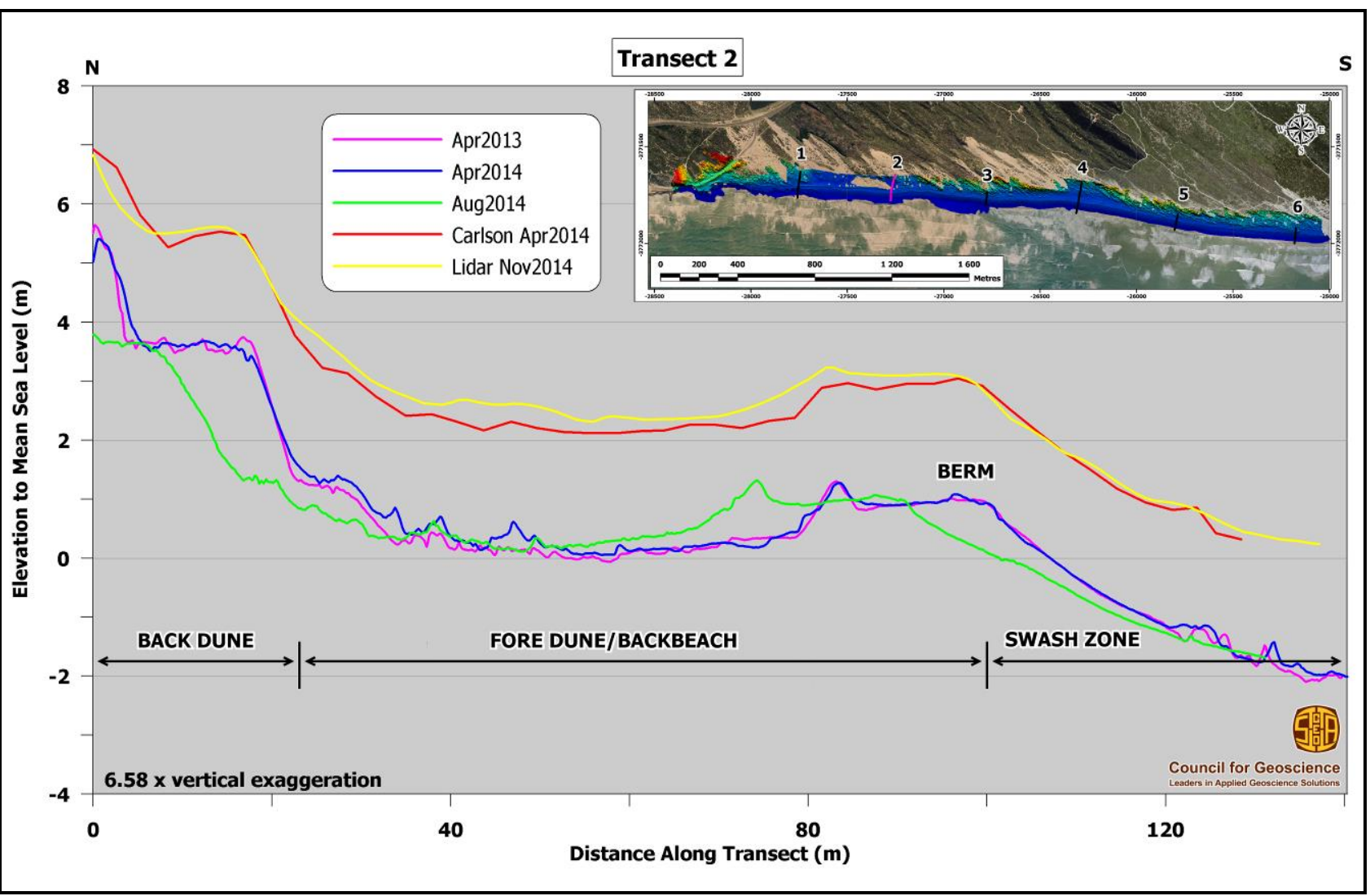

Figure 2. Comparison of the different elevation profiles along Transect 2. Inset map reflects relative position of transect within the study area (magenta line).

All of the transects show that for the yearly surveys (blue and magenta lines) the difference between profile elevations is negligible implying a dynamic state of near equilibrium. When comparing the seasonal surveys, differences are clear on the transects characterised by a sandier substrate. On most of the profiles there is a landward shift of the beach berm and erosion of the backbeach/foredune area. On transects four and five there is evidence of accretion in the swash zone during this period.

An additional transect was made across the area where road failure has occurred in the western portion of the study area (Figure 3). These data illustrate the rate of cliff retreat over a period of one year and the mechanism of cliff retreat. Over one year the rate of retreat is $1.7 \mathrm{~m} / \mathrm{yr}$ at the top of the profile, $2.5 \mathrm{~m} / \mathrm{yr}$ in the middle and $2.4 \mathrm{~m} / \mathrm{yr}$ at the base, therefore an average rate of retreat of $2.2 \mathrm{~m} / \mathrm{yr}$. Comparison of the seasonal change in profiles shows how the toe of any near vertical section is first eroded until a critical gradient is reached upon which the slope will fail and material will be eroded from the cliff face. The seasonal comparison demonstrates how during the winter months sediment is transported from the northwest, evident by the accumulation of sediment on top of the road. 


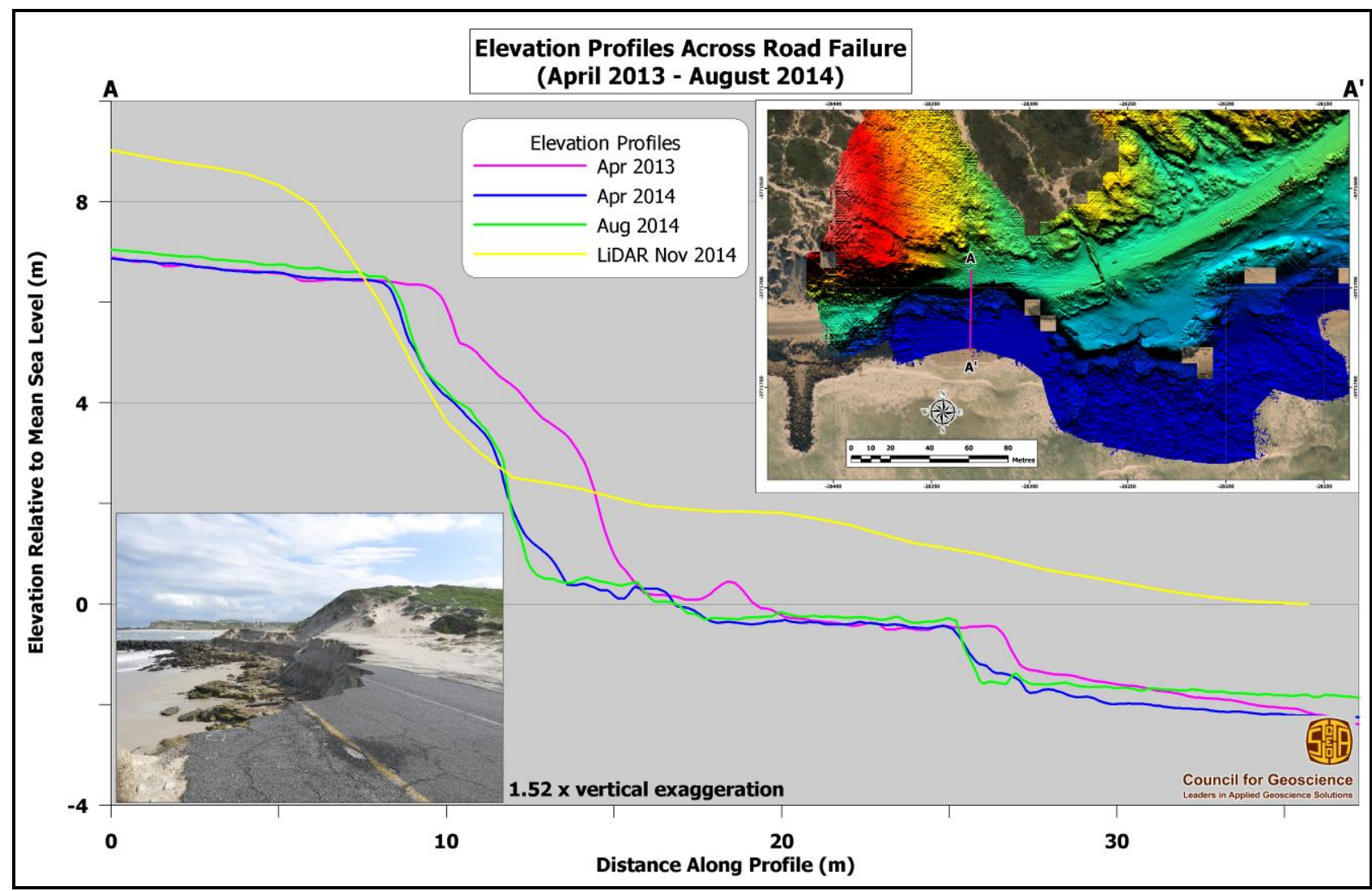

Figure 3. Comparison of the different elevation profiles across the road failure. Top right inset map reflects relative position of transect within the study area (magenta line). Bottom left is a picture courtesy of W. Van Zyl of the failed road.

\subsection{Erosion and accretion}

Because the laser scanning datasets are all accurately referenced to the same benchmark which was placed in the middle of the survey area relative to MSL, comment can be made on volume changes between the different datasets. The volume and areal extent changes have been summarised in Table 1 and Figure 4.

Table 1. Erosional and accretionary changes of the survey area

\begin{tabular}{|c|c|c|c|c|c|c|c|}
\hline \multirow{2}{*}{ Time Period } & \multirow{2}{*}{$\begin{array}{l}\text { Median } \\
\text { (m) }\end{array}$} & \multirow{2}{*}{$\begin{array}{c}\text { Mean } \\
(\mathbf{m})\end{array}$} & \multirow{2}{*}{$\begin{array}{c}\text { Std Deviation } \\
(\mathbf{m})\end{array}$} & \multicolumn{2}{|c|}{ Aerial Extent $\left(\mathrm{m}^{2}\right)$} & \multicolumn{2}{|c|}{ Volume $\left(\mathbf{m}^{3}\right)$} \\
\hline & & & & Accretion & Erosion & Accretion & Erosion \\
\hline $\begin{array}{c}\text { April } 2013 \text { - } \\
\text { April } 2014\end{array}$ & -0.05 & -0.08 & 0.28 & $165,383.85$ & $299,151.01$ & $24,975.05$ & $64,559.42$ \\
\hline $\begin{array}{l}\text { April } 2014 \text { - } \\
\text { August } 2014\end{array}$ & -0.05 & -0.08 & 0.21 & $108,727.34$ & $312,252.10$ & $13,317.92$ & $47,929.61$ \\
\hline
\end{tabular}

The datasets spanning approximately one year show the largest variation in volumetric changes although practically, these are small incremental changes. The generalised pattern shows deposition 
(accretion) along the foreshore (swash zone) of the beach profile and toes of the more rugged cliff zones. The backbeach/foredune area is characterised by erosion with a relative loss in sediment volumes in this area. In some places accretion has occurred in this zone yet it appears localised.

The dataset spanning the typical winter period for False Bay shows much smaller relative changes. It shows accretion along the base of the swash zone with erosion characterising the top of the swash zone profile. Accretion is evident slightly landward of the berm position from the April 2014 dataset. The amount of erosion from the backbeach/foredune area is much more subdued than the yearly dataset but does show a generalised erosional trend in this area.

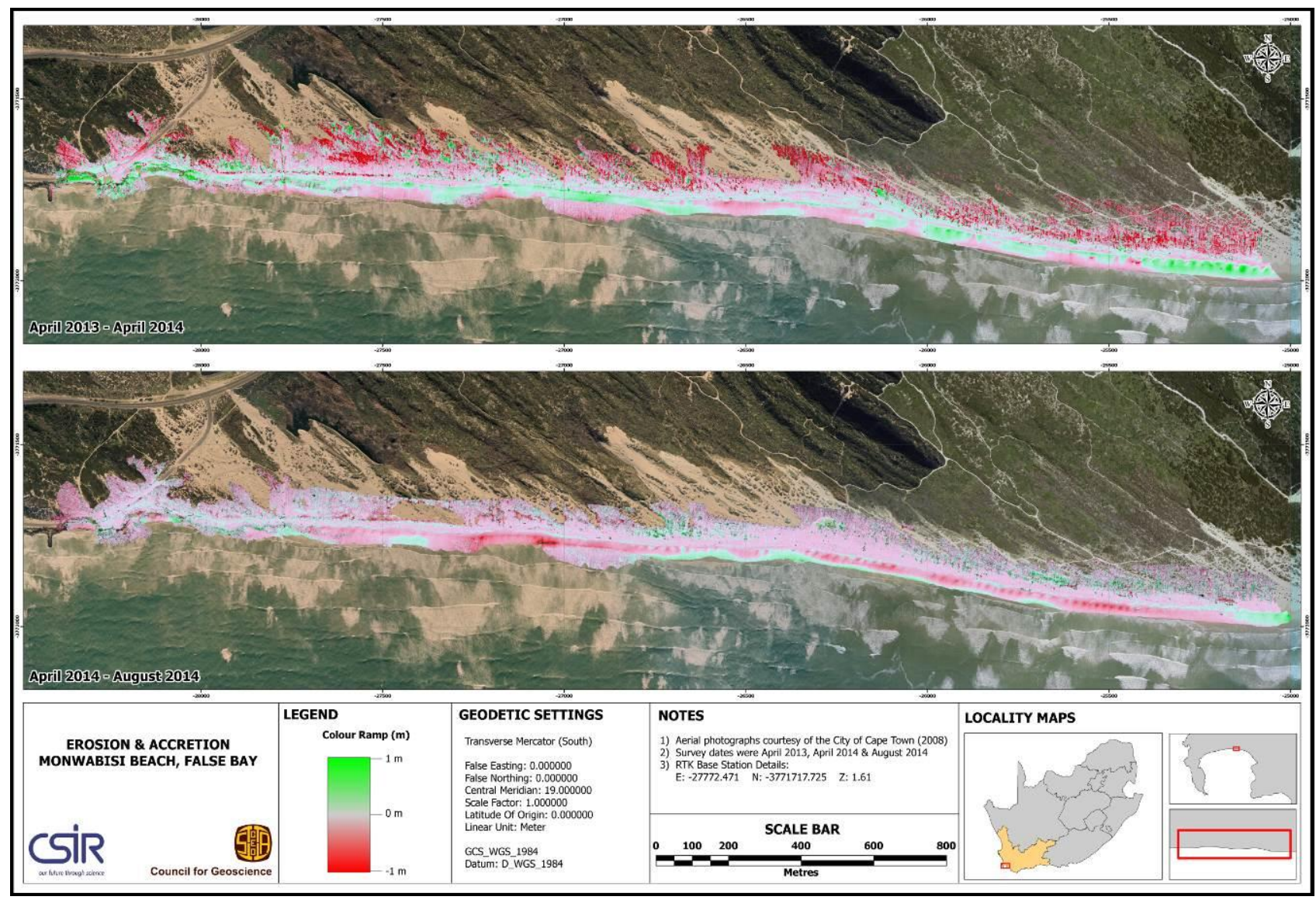

Figure 4. Summary map of sediment erosion (red) and accretion (green) for Monwabisi Beach over a year scale (above) and a seasonal scale (blow).

The net trend however is one of erosion (Table 1) with sediment moving towards the north.

\section{Discussion}

Various authors have defined the coastal hydrodynamic setting of the Cape Peninsula as a wave and storm dominated coastline (Rossouw, 1984; Theron and Schoonees, 2007; MacHutchon, 2008; MacHutchon, 2013). Within these types of coastline, waves and wave induced currents are the dominant mechanism for moving and depositing sand on shorefaces and beaches of the open coast, 
although winds, river discharge, tidal currents and Ekman flows variously act as transporting agents (Carter and Woodroffe, 1994). For Monwabisi Beach the amount of terrigenous sediment supplied by rivers is negligible with no major rivers present in the vicinity of the study area. Sediment is however derived from the reworking of coastal cliffs to the immediate west of the study area. This is believed to be a secondary sediment source with the primary source postulated to be derived from coastal Pleistocene deposits deposited during glacial maxima and presently situated on the now drowned seafloor of False Bay (Rogers, 1977; Compton, 2001; MacHutchon, 2013). Longshore drift vectors show a bimodal distribution pattern to the east and west as a result of the shoreline oblique dominant incident wave vectors and its interplay with wind directions.

Monwabisi Beach displays the beach cycle trend as demonstrated by Sonu and van Beek (1971). During fairweather conditions, waves experienced along the coastline are relatively low amplitude; long period swells with a shallow wave base. During these conditions the lower beachface is not affected by the incident waves and fine grained sediment can settle out of suspension where it is reworked by biogenic organisms (Reading, 1986). Along the upper beachface wave induced currents associated with shoaling, breaker and surf zones, transport sediment landwards. The loss of sediment from this zone via rip currents is negligible and the nett result is the upper beachface aggrades (accretes) (Reading, 1986). This pattern has been reinforced for the study area through comparison of the various datasets. During storm conditions the wave base is deepened by higher amplitude waves causing the lower beachface to experience wave induced processes and reactivation of sediment transport. The upper beachface is extensively eroded during storms and sediment is redeposited as washover fans and swept seaward to the lower beachface and offshore areas (Reading, 1986). This trend too is reinforced for the study area with a landward shift in berm positions and erosion immediately seaward of this. Once landward of the berm Aeolian processes are the dominant factor effecting the coastal deposits with sediment primarily being transported by the regular southeasterly gales experienced along the Cape Peninsula. The evidence supporting this is the parallel alignment of the non-vegetated coastal dunes along the northern rim of the study area and the amount of erosion seen when comparing the yearly datasets.

Rates of erosion and accretion are difficult to assess as the datasets do not span a sufficient period of time or sufficient frequency. Both yearly and seasonal datasets show a net loss of sediment but the rate at which this occurs could only confidently be reported on over a dataset spanning 10 or more years. The seasonal trend too shows a similar pattern to the annual trend yet the datasets might not encompass the average storm conditions experienced by the Cape Peninsula and could be more reflective of an end member situation. The author is however confident of the nett erosional trend as comparison of an aerial photograph from 2008 with the elevation surfaces 
from this study has shown how much sediment has been denuded from the study area, re-enforced by personal observation from visiting the site over a two year period and first hand noting the increase in rock outcrop exposure.

Studies done by the CSIR (1995) where DEM's were produced using a combination of total station topographic beach surveys and nearshore singlebeam echosounder surveys calculated the potential gross longshore sediment transport rate for the site to be between $490,000 \mathrm{~m}^{3} / \mathrm{yr}$ to $530,000 \mathrm{~m}^{3} / \mathrm{yr}$, with the potential nett eastbound rate between $100,000 \mathrm{~m}^{3} / \mathrm{yr}$ and $140,000 \mathrm{~m}^{3} / \mathrm{yr}$. Rates are expected to be slightly lower as a result of the occurrence of rocky nearshore areas which limit sediment availability. The approximate value for longshore drift rates calculated from the laser scanning datasets is $24,000 \mathrm{~m}^{3} / \mathrm{yr}$ which is much lower than the potential budget calculated by the CSIR but mention should be made that the current study only addresses volumes from the subaerial part of the swash zone and does not use data from within the breakers or surf zone. The CSIR also calculated the rate at which sand is blown seasonally by applying the Swart (1986) method which employs formulae relating sand size $(>80 \mu \mathrm{m})$ to wind speed, assuming dry, cohesionless sand of unlimited quantity blowing along a flat unvegetated surface and therefore represent maximum potential transports. These results yielded the average nett, potential rate of the northbound sand to be between $1,600 \mathrm{~m}^{3} / \mathrm{yr}$ and $4,200 \mathrm{~m}^{3} / \mathrm{yr}$ (CSIR, 2001). The value obtained from the yearly comparison from the current study shows erosional volumes much larger than this (approximately $58,000 \mathrm{~m}^{3} / \mathrm{yr}$ ). This however is not the nett northward transport and is more indicative of the gross volume of eroded sediment from the landward side of the berm.

Unlike the changes in sediment volume data, the profiles constructed across the area where road failure has occurred within the study area show definite rates of cliff retreat. These rates are anticipated to be higher during periods characterised by large storm events. Higher rates of erosion were measured at the base and middle of the cliff with the lowest toward the top of the profile. An explanation for this is the mechanism behind how the cliff retreats. The seasonal comparison shows how the toe of any near vertical section is preferentially eroded. This is the zone of highest wave energy as it meets the vertical obstruction. As the toe is undermined, a critical point will be reached whereby the weight of the sediment above this zone will become greater than the cohesive, frictional forces which hold it in equilibrium and slope failure will occur. This will result in the formation of an exponential shaped slope profile and for the process of cliff retreat to continue once again. The average rate of cliff retreat over the annual period surveyed was $2.2 \mathrm{~m} / \mathrm{yr}$.

All of these data represent the "normal" conditions experienced around the Cape Peninsula. There are times however when abnormal storm conditions are experienced as occurred during September 2008. This storm event occurred between 31 August and 4 September 2008 and caused 
considerable damage to the coastline. It was characterised by deep water significant wave heights of $10.7 \mathrm{~m}$. This storm has been estimated by Theron et al. (2010) to have a return period of approximately 10 years. The damage was intensified by the fact that the storm occurred one day after spring tides and that tidal elevations were already $0.5 \mathrm{~m}$ above the predicted levels, most likely as a result of storm surge and local barometric effects (Mather and Theron, 2011). Wave run-up heights were measured at seventeen beaches around the Cape Peninsula coastline and these peaked at 7.9m above MSL (Mather, 2011). During such episodes the erosive energy delivered to the coastline would have been considerable and it is expected that the rate of cliff retreat would be at its maximum.

\section{Conclusions}

These data have shown some of the available techniques for monitoring coastal erosion and have successfully demonstrated how accurate comment can be delivered on sediment dynamics of the coastal zone through analysis of successive, repetitive surveys. Importantly all of the surveys need to be accurately referenced to the same benchmark so that quantitative and qualitative comparisons can be made between the various datasets. Dataset requirements are for the highest density, most affordable technique that affords $100 \%$ coverage of the study area and constitutes digital elevation surfaces for the relevant areas being monitored. Although conventional beach profile lines are useful for describing sedimentological trends, these data cannot be used to accurately assess volumes of sediment change.

The laser scanning datasets have shown that sediment moves from south to north with a nett erosional trend. This means that the beaches along the northern rim of False Bay are progressively losing sand leaving behind exposed lithological outcrops. Where coastal infrastructure is close to the water's edge this too can become buried or destroyed as in the case of the failed road within the study area. The average rate of cliff retreat has been shown to be approximately $2.2 \mathrm{~m} / \mathrm{yr}$. This rate is anticipated to increase markedly during large storm events such as experienced in September 2008, which has a return period of 10 years. Substrate type will also affect the rate of retreat with unconsolidated sediment being more easily eroded than competent lithological beds.

Although these data has shown that accurate figures can be derived for erosion and accretion, the rates of change of these parameters is very hard to assess with a high degree of confidence due to the relative paucity of elevation datasets. Acquisition must take place as frequently as at monthly intervals and spanning at least 10 years before actual sediment flux values can be calculated with both a high degree of accuracy and confidence. This study has however demonstrated reliable 
monitoring techniques that could be rolled out on a larger scale to the majority of coastal zones around South Africa to help manage and hopefully prevent or mitigate any future catastrophic damage to coastal infrastructure and negative impact on people's lives. A brief summary of the positive and negative aspects of the various monitoring techniques has been provided in Table 2 .

Table 2. Comparisons of different monitoring techniques from this study

\begin{tabular}{ccccc}
\hline Suite & $\begin{array}{c}\text { Cost per } \\
\text { Survey }\end{array}$ & DEM Resolution & Pros & Cons \\
\hline LiDAR & $\pm \mathrm{R} 200,000$ & $\begin{array}{c}\text { 2m from flying } \\
\text { height of 1,000m }\end{array}$ & $\begin{array}{c}100 \% \text { coverage of large } \\
\text { areas. Best way to safely map } \\
\text { vertical sea cliffs }\end{array}$ & $\begin{array}{c}\text { Expensive and needs } \\
\text { clear weather }\end{array}$ \\
Mobile laser & $\pm \mathrm{R} 60,000$ & 0.25m & $\begin{array}{c}\text { 100\% coverage of } \\
\text { intermediate areas. Highest } \\
\text { DEM resolution }\end{array}$ & $\begin{array}{c}\text { Heavily controlled by } \\
\text { beach access, optical } \\
\text { shadowing }\end{array}$ \\
Beach & $\pm \mathrm{R} 2,000$ & $\begin{array}{c}\text { Every second along } \\
\text { profile lines. DEM } \\
\text { is approx. 280m }\end{array}$ & Cheap and logistically easy & $\begin{array}{c}\text { Sparse data coverage } \\
\text { not suitable for } \\
\text { volume calculations }\end{array}$ \\
\hline
\end{tabular}

\section{References}

Atkins, GR 1970, 'Thermal structure and salinity of False Bay', Transactions of the Royal Society of South Africa, vol. 39, number 2, pp. 117-128.

Carter, RWG. and Woodroffe, CD (eds), 1994, Coastal evolution: late Quaternary shoreline morphodynamics, Cambridge University Press.

Compton, JS 2001, 'Holocene sea-level fluctuations inferred from the evolution of depositional environments of the southern Langebaan Lagoon salt marsh, South Africa', The Holocene, vol. 11, number 4, pp. 395-405.

CSIR 1983, 'Coastal erosion along Baden Powell Drive, Strandfontein', CSIR Report C/SEA 8399, Stellenbosch: CSIR.

CSIR 1995, 'Monwabisi: beach and tidal pool works', CSIR Report EMAS-C 95071, Stellenbosch: CSIR.

CSIR 2001, 'Solutions for the wind-blown sand problems at Monwabisi', CSIR Report ENV-S-C 2001-052, Stellenbosch: CSIR.

Hutchings, L, van der Lingen, CD, Shannon, LJ, Crawford, RJM, Verheye, HMS, Bartholomae, CH, van der Plas, AK, Louw, D, Kreiner, A, Ostrowski, M, Fidel, Q, Barlow, RG, Lamont, T, Coetzee, J, Shillington, F, Veitch, J, Currie, JC and Monteiro, PMS 2009, 'The Benguela Current: an ecosystem of four components', Ocenography, vol. 83, pp. 15-32. 
Komar, PD 1998, Beach processes and sedimentation, $2^{\text {nd }}$ edition illustrated, Prentice Hall.

MacHutchon, KR 2008, 'The characterisation of South African sea storms', Unpublished MSc Thesis, Department of Civil Engineering, University of Stellenbosch.

MacHutchon, MR 2013, 'The geological evolution and sedimentary dynamics of Hout Bay, South Africa', Bulletin of the Council for Geoscience, vol. 148.

Mather, AA 2011, 'Sea level rise and its anticipated impacts along the east coast of South Africa', in: L Zietsman (ed), Observations on environmental change in South Africa, SUN Press.

Mather, AA and Theron, AK 2011, Recent extreme events along the coast of South Africa (Draft Report), viewed 15 October 2014, $<$ http://www.cfoo.co.za/docs/stormsurge/Item\%203\%20Extreme\%20events\%20AM\%20et\%20al\%2 Orevised.pdf $\geq$

Reading, HG (ed) 1986, Sedimentary environments and facies, $2^{\text {nd }}$ edition,. Blackwell Scientific Publications.

Rogers, J 1977, 'Sedimentation of the Continental Margin off the Orange River and the Namib Desert', Bulletin of the Geological Survey of South Africa/University of Cape Town Marine Geoscience Unit, vol. 7.

Rossouw, J 1984, 'Review of existing wave data, wave climate and design waves for South African and South West African (Namibian) coastal waters', CSIR Report T/Sea 8401, Stellenbosch.

SAN 2014, South African tide tables. SANHO-2, Tokai: South African Navy.

Schoonees, JS, Theron, AK and Coppoolse, RC 1999, 'Temporary groynes for short-term field calibration of longshore transport: a case study', in, Coastal sediments '99. Long Island, New York: ASCE.

Sonu, CJ and Van Beek, JL 1971, 'Systematic beach changes in the Outer Banks, North Carolina', Journal of Geology, vol. 74, pp. 416-425.

Swart, DH 1986, 'Prediction of wind-blown transport rates', in, $20^{\text {th }}$ International Conference on Coastal Engineering, Taipei Taiwan, vol. 2, pp. 1595-1611.

Swart, DH and Schoonees, JS 1994, 'Beach improvement schemes in False Bay', in, $24^{\text {th }}$ International Conference on Coastal Engineering, ASCE, Kobe, vol. 3, pp.2668-2682.

Terhorst, A 1988, 'The seafloor environment off Simon's Town in False Bay, revealed by side-scan sonar, bottom sampling, diver observations and underwater photography', Bulletin of the Geological Survey of South Africa/University of Cape Town Marine Geoscience Unit, vol. 22.

Theron, AK, Diedricks, G, Mahery, A and Rossouw, M 2010, 'Potential impacts of climate change on the coastal zone: how far from the sea should we be?'South African Risk and Vulnerability Atlas. Department of Science and Technology. 
South African Journal of Geomatics, Vol. 4, No. 2, June 2015

Theron, AK and Schoonees, JS 2007, 'Sand transport at and shoreline response to a breakwater attached to a large tidal pool at Monwabisi, Cape Town', Journal of the South African Institution of Civil Engineering, vol. 49, number 2, pp. 2-9.

Unterner, M, Wigley, RA, Van Zyl, FW, Cawthra, HC, MacHutchon, MR, 'The vulnerability of the South African coastline to erosion', Report of the Council for Geoscience, Cape Town, South Africa, number 2011-0190.

Van Foreest, D and Brundrit, GB 1985, 'Numerical modelling of the southern Benguela system', in, LV Shannon (ed). South African Ocean Colour Experiment. Cape Town: Sea Fisheries Research Institution.

Van Foreest, D and Jury, MR 1985, 'A numerical model of the wind-driven circulation in False Bay', South African Journal of Science, vol. 81, pp. 312-213.

Windfinder 2014, viewed 01 October 2014 <http://www.windfinder.com> 